\title{
Pengembangan Model Kemitraan Sekolah Dengan Orang Tua Melalui Media Sosial Dalam Peningkatan Mutu Berbasis Sekolah di Sekolah Menengah Swasta
}

\author{
Mutia Ayu Krismanda \\ Magister Manajemen Pendidikan \\ Universitas Kristen Satya Wacana \\ mutia.krismanda@gmail.com \\ Bambang Ismanto \\ Magister Manajemen Pendidikan \\ Universitas Kristen Satya Wacana \\ bam_ismanto@yahoo.com \\ Ade Iriani \\ Magister Manajemen Pendidikan \\ Universitas Kristen Satya Wacana \\ adeiriani@gmail.com
}

\begin{abstract}
The purpose of this research is to analyze the factual model of school partnership with parents through social media in school-based quality improvement management in SMA Kristen 1 Salatiga and result in the development of school partnership model with parents through social media in school-based quality improvement management in private high schools. It is Research and Development $(R \& D)$ research. Data collection techniques used interviews and documentation studies. The development phase is done through (1) Potential and Problem, (2) Data Collection, (3) Product Design, (4) Design Validation, and (5) Design Repair. The results showed that SMA Kristen 1 Salatiga had run the family education program quite well. Several activities in the family education program at the school has been implemented before the schools get funding from the government partnership program. Schools have also begun to seek the use of social media as a means of strengthening communication with parents and other stakeholders, but nevertheless in its development in the field of management has not been maximized. The researchers also found no model formulated by the school associated with this family education program because the new school programmed the partnership into a family education program within one year. The product of this research is a school partnership model with parents through social media at a private high school equipped with guides for the implementing parties.
\end{abstract}

Keywords: Research and Development (R\&D), Model, School and Parents Partnership, Social Media

\section{Article Info}


Pengembangan Model Kemitraan Sekolah Dengan Orang Tua Melalui ... | Mutia Ayu Krismanda, dkk.

\section{PENDAHULUAN}

Demi tercapainya peningkatan mutu yang diharapkan, sekolah perlu memahami dan melaksanakan prinsip dan karakteristik MBS atau yang kini disebut dengan Manajemen Peningkatan Mutu Berbasis Sekolah (MPMBS). Hal ini seperti yang telah diatur oleh pemerintah dalam Undang-Undang No. 20 Tahun 2003 tentang Sistem Pendidikan Nasional Pasal 51 ayat 1 yang menyatakan bahwa pengelolaan satuan pendidikan anak usia dini, pendidikan dasar, dan pendidikan menengah dilaksanakan berdasarkan standar pelayanan minimal dengan prinsip manajemen berbasis sekolah/ madrasah. Manajemen Peningkatan Mutu Berbasis Sekolah dapat disimpulkan sebagai sistem pengelolaan persekolahan yang mengacu pada manajemen sumber daya secara mandiri untuk meningkatkan mutu sekolah dengan memberikan kewenangan dan kekuasaan kepada sekolah yang melibatkan partisipasi masyarakat, warga sekolah dan orang tua secara langsung pada proses pengambilan keputusan. Pengelolaan sekolah juga hendaknya disesuaikan dengan potensi, tuntutan dan kebutuhan sekolah yang bersangkutan dan ditetapkan oleh masing-masing sekolah sesuai dengan tujuan dan strateginya, sehingga dapat mengarahkan organisasi sekolah kedepan (Slameto, 2015: 13; Daryanto, 2013: 176; Mulyasa, 2012: 177). MPMBS ini bertujuan memandirikan dan memberdayakan sekolah melalui pemberian kewenangan (otonomi) terhadap sekolah dalam mengelola sumber daya yang dimiliki secara efektif dan efisien, serta mendorong sekolah untuk melakukan pengambilan keputusan yang tepat secara partisipatif, transparan, dan akuntabel dalam mencapai tujuan yang telah ditetapkan (Syaifudin, 2013; Mulyasa, 2012:179).

Salah satu dari ketiga pilar MBS yaitu peran serta masyarakat. Dapat disimpulkan dari pernyataan Slameto

(2015) dan Mulyasa (2012) bahwa penerapan MPMBS khususnya dalam meningkatkan partisipasi orang tua dan masyarakat, maka sekolah dapat melakukan hal-hal yang berkaitan sebagai berikut: (1) Penggunaan sumber daya pendidikan lebih efisien dan efektif bilamana dikontrol oleh masyarakat setempat dengan mengembangkan norma kebersamaan dan kerjasama dengan kegiatan belajar dan perencanaan bersama; (2) Keterlibatan semua warga sekolah dan masyarakat dalam pengelolan sekolah khusunya pengambilan keputusan sekolah menciptakan transparansi dan demokrasi yang sehat, salah caranya dengan memberikan kepada "dewan sekolah" sebagai badan pembuat keputusan bukan sekedar penasehat; (3) Sekolah dapat bertanggung jawab tentang mutu pendidikan masing-masing kepada pemerintah, orang tua peserta didik, dan masyarakat pada umumnya, sehingga dia akan berupaya semaksimal mungkin untuk melaksanakan dan mencapai sasaran mutu pendidikan yang telah direncanakan, hal ini berarti tidak hanya melaksanakan MBS dengan mengimplikasikan peningkatan peluang wakil orang tua murid dan masyarakat untuk memberikan masukan dalam pegambilan keputusan disekolah, melainkan juga meyediakan pelatihan untuk menolong mereka agar lebih mampu menjadi partisipan dalam upaya perencanaan maupun pengambilan keputusan; (4) Sekolah dapat secara cepat merespon aspirasi masyarakat dan lingkungan yang berubah dengan cepat.

Peran serta masyarakat dalam satuan pendidikan diwadahi melalui komite sekolah. Komite sekolah meliputi orang tua dan stakeholder lainnya. Secara normatif Komite Sekolah semestinya menjalankan empat fungsinya yaitu fungsi sebagai pemberi pertimbangan dalam pengambilan keputusan, fungsi kontrol dan akuntabilitas publik, fungsi pendukung, serta fungsi mediator antara sekolah dengan masyarakat yang diwakilinya (Rodliyah, 2013: 43). Namun dari beberapa penelitian (Armansayah, 2009, Gelgel, 2005, Junaedi, 2011, Larasati, 2009, Mulyono, 2014) pada kenyataanya masih banyak ditemukan komite sekolah yang belum maksimal 
menjalankan fungsi dan perannya. Sehingga saat ini mulai bermunculan kembali pola-pola partisipasi sekolah yang langsung kepada orang tua yang dianggap sebagai bagian dari masyarakat. Pola partisipasi sekolah dan orang tua inilah yang diangkat menjadi topik penelitian ini.

Partisipasi atau keterlibatan orang tua dalam satuan pendidikan tidak hanya dibutuhkan pada tingkat taman kanak-kanan atau sekolah dasar saja namun di tingkat sekolah menengah pula. Dalam usia 11-17 tahun, anak-anak justru sedang berada pada masa puberitas, transisi dan pengembangan kemampuan berpikir abstrak. Pada usia tersebut, anak-anak juga dianggap sebagai anak pada usia yang tingkat kerawanannya tinggi. Mereka dapat mudah terpengaruh dengan narkoba, tawuran, putus sekolah dan kejahatan lain serta mengalami gangguan psikologi. Dalam masa seperti ini dukungan dari orang tua sangat dibutuhkan untuk menghindari hal-hal tersebut. Kemitraan sekolah dengan orang tua pada tingkat sekolah menengah memang memiliki perbedaan dengan tingkat sekolah dasar. Dalam tingkat sekolah menengah, anak lebih membutuhkan hubungan yang mengutamakan kepedulian dan kepercayaan terhadap anak. Para siswa sekolah menengah memerlukan kesempatan untuk membentuk identitas diri mereka masing-masing, mengekspresikan diri dan terlibat dalam pengalaman yang memiliki tantangan yang dapat mengembangkan kemapuan dan harga diri mereka. Mereka menginginkan otonomi, kebebasan dan waktu dengan teman sebaya namun disaat yang sama mereka juga membutuhkan orang tua atau orang dewasa yang dapat diandalkan. (Havard Family Research Project, 2007: 1).

Model partisipasi orang tua di sekolah merupakan konsep yang multidimensional. Bahkan sering juga digunakan istilah-istilah lain dan tidak seragam seperti: parent participation, parent involvement, home-school connection, home-school participation atau family-school relationships (Greenfield 2003:
2). Maka dalam memahami model partisipasi orang tua di sekolah diperlukan pemahaman beberapa model yang telah terdefinisikan.

Havard Family Research Project (2002: 1-2) mengembangkan empat model partisipasi orang tua seperti berikut ini. 1) Model Parenting Practice: keyakinan, sikap dan kegiatan-kegiatan orang tua untuk mendukung anaknya belajar baik disekolah maupun dirumah. 2) Model School-Family Partnership: didasarkan ide bahwa keluarga dan sekolah merupakan lingkungan yang mempengaruhi belajar anak, walau begitu sekolah mempunyai tanggung jawab utama untuk menjangkau orang tua dan masyarakat, maka perlu dikembangkan kemitraan antar pihak. 3) Model Democratic Participation: partisispiasi orang tua dapat berarti sebagai partisipasi dalam kelembagaan masyarakat. Orang tua dan masyarakat adalah pihak yang memiliki kekuatan sebagai agen pembaruan sosial dapat berperan serta secara efektif dalam reformasi sekolah (MBS) baik secara konfrontatif maupun kolaboratif. 4) Model School Choice: partisipasi orang tua terkait dengan pilihan sekolah, sekolah manayang dipilih orang tua untuk anaknya. Pemilihan sekolah dan program-programnya sesuai prinsip pasar itu menentukan partisipasi orang tua anak.

Menyadari pentingnya pola partisipasi orang tua di sekolah, Direktorat Jenderal Pendidikan Anak Usia Dini dan Pendidikan Masyarakat juga membentuk program Kemitraan Sekolah dengan Keluarga dan Masyarakat. Salah satu sekolah yang ditunjuk sebagai sekolah percontohan program tersebut adalah SMA Kristen 1 Salatiga. Berdasarkan studi pendahuluan di SMA Kristen 1 Salatiga yang mengadakan program Pendidikan Keluarga, maka peneliti melihat pentingnya program kemitraan sekolah yang mendorong orang tua dalam keterlibatannya pada pendidikan seluruh peserta didik. Partisipasi atau keterlibatan orang tua dalam satuan pendidikan tidak hanya dibutuhkan pada tingkat taman kanak-kanan atau sekolah dasar saja namun di tingkat sekolah menengah pula. 
Pengembangan Model Kemitraan Sekolah Dengan Orang Tua Melalui ... | Mutia Ayu Krismanda, dkk.

Hasil studi pendahuluan menunjukan bahwa SMA Kristen 1 Salatiga telah dirasa cukup mampu untuk mengembangkan program sekolah berbasis kemitraan. Meskipun sudah diadakan beberapa program kemitraan dengan keluarga yang sudah dirasakan manfaatnya, namun program ini masih perlu dikembangkan lagi. Beberapa masalah anak yang saat ini harus segera ditangani oleh sekolah yaitu meliputi pengawasan dan pengenndalian anak dalam menggunakan gadget dan media sosial serta kedekatan anak dengan orang tua sehingga menimbulkan catatan buruk bagi prestasi anak dan kedisiplinanya disekolah. Jika hal ini tidak segera mendapatkan solusinya maka akan berdampak pada prestasi siswa dan menurunnya mutu sekolah. Oleh karena itu, sekolah harus terus meningkatkan kerjasama dengan orang tua atau wali murid untuk mengatasi masalah tersebut.

Dalam mewujudkan program pendidikan keluarga sekolah juga telah berupaya menjalin komunikasi dengan orang tua atau wali murid lebih intens lagi melalui website sekolah, akun facebook, pesan singkat, whatsapp (WA), BBM (Blackberry Massenger) dan email sebagai sarana komunikasi di era digital ini. Penggunaan media sosial dianggap sebagai inovasi yang positif dalam suatu program kemitraan. Mazza (2013) melihat beberapa fungsi media sosial disekolah-sekolah yang sudah menggunakannya. Fungsi media sosial dalam memperkuat kemitraan sekolah dengan keluarga dan masyarakan serta pemangku kepentingan lainnya diantaranya yaitu: (1) Menginformasikan orang tua mengenai kegiatan sekolah yang up to date; (2) Memberikan kesempatan komunitas untuk mengenal para pendidik dan tenaga pendidik sekolah; (3) Mendorong partisipasi global; (4) Membangun kepercayaan; (5) Mendukung dana bagi kegiatan sekolah; (6) Berbagi fakta mengenai pencapaian atau prestasi siswa, pendidik atau tenaga kependidikan; (7) Menggungah pengingat hal-hal penting seperti rapat pertemuan atau kegiatan sekolah pada keluarga; (8) Berbagi sumber bacaan atau artikel yang dapat mendukung atau mendorong pedidikan dirumah; (9) Menunjukan penghargaan kepada pemangku kepentingan; (10) Berbagi informasi untuk kegiatan atau peristiwa masa lalu, sekarang dan yang akan datang. Selain itu studi Cox (2012) juga telah menemukan hasil positif dari penggunaan media sosial di sekolah menggunakan empat tema besar. Keempat tema besar itu meliputi interaksi, hubungan, dampak dan harapan. Berdasarkan tema tersebut dihasilkan bahwa pertama, alat komunikasi media sosial memungkinkan interaksi yang lebih luas antara adminstrasi sekolah dan para pemangku kepentingan, kedua alat komunikasi media sosial memberikan hubungan yang lebih kuat kepada peran pemangku kepentingan lokal, memberikan jaringan rekan kerja sesama pendidik pada dunia yang lebih luas, ketiga penggunaan media sosial dapat memiliki dampak signifikan dalam perkembangan keprofesionalan administrator sekolah, dan yang terakhir penggunaan media sosial adalah sebuah harapan yang berarti bukan hanya sekedar sebuah pilihan. Dalam hal ini penggunaan media sosial merupakan harapan akan penguatan kemitraan yang lebih baik. Melihat hal tersebut penggunaan media sosial dalam pengembangannya di bidang manajemen pada program kemitraan di SMA Kristen 1 Salatiga saat itu dirasa belum maksimal. Permasalahan lain yang ditemukan dalam penelitian ini adalah belum adanya model yang dibuat sekolah terkait dengan program pendidikan keluarga ini karena sekolah baru memprogramkan kegiatan kemitraan menjadi program pendidikan keluarga dalam satu tahun ini. Hasil penelitian ini diharapkan dapat menjadi saran-saran perbaikan dan pengembangan model kemitraan sekolah dengan orang tua melalui media sosial untuk mewujudkan program pendidikan keluarga dalam rangka meningkatkan mutu sekolah yang dapat menjadi contoh bagi sekolah lainnya juga, khususnya sekolah menengah swasta. 


\section{METODE PENELITIAN}

Penelitian ini merupakan penelitian dan pengembangan atau Research and Development ( $\mathrm{R} \& \mathrm{D})$ dengan menggunakan langkah-langkah dari Sugiyono yang dilaksanakan dengan tujuan untuk menyusun pengembangan model kemitraan sekolah dengan orang tua melalui media sosial dalam manajemen peningkatan mutu berbasis sekolah di sekolah menengah swasta. Namun dalam penelitian dan pengembangan ini hanya dibatasi sampai pada tahap kelima dari langkahlangkah pengembangan Sugiyono tersebut, yaitu : 1) potensi dan masalah; 2) pengumpulan data; 3) desain produk; 4) validasi desain; 5) revisi desain. Hal ini dilakukan sampai menghasilkan produk saja yang berupa model kemitraan sekolah dengan orang tua melalui media sosial.

Penelitian ini dilakukan di SMA Kristen 1 Salatiga dengan sumber data yang terdiri dari stakeholder yang saling terkait dengan penyelenggaran dan pengelolaan program kemitraan keluarga di SMA Kristen 1 Salatiga yaitu: (1) Kepala Sekolah; (2) Ketua program pendidikan

keluarga Keluarga (Wakasek Humas); (3) Koordinator Program Kemitraan (Guru BK); (4) Sekretaris program pendidikan keluarga (Pengelola sistem informasi sekolah). Teknik Pengumpulan data yang digunakan adalah melalui wawancara, studi dokumentasi dan FGD. Metode analisis data yang digunakan dalam penelitian ini yaitu analisis SWOT dan MAS. Tahap yang digunakan adalah menggunakan analisis matrik IFAS (Internal Factors Analysis Summary), dan analisis matrik EFAS (External Factors Analysis Summary) berdasarkan analisis matrik SWOT (Strengths, Weaknesses, Opportunities and Threats). Selain itu hasil dari analisis SWOT dimodifikasi dengan MAS (Modify, Add, Size), hal ini dimaksudkan agar hasil dari penelitian ini dapat menjadi suatu ide baru bagi sekolah yang tentunya disesuaikan oleh kondisi sekolah.

\section{HASIL DAN PEMBAHASAN Hasil Penelitian}

Secara aktif SMA Kristen 1 Salatiga telah memprakarsai beberapa program sesuai analisis kebutuhan yang dilakukan sekolah. Beberapa kegiatan dalam program pendidikan keluarga sesungguhnya telah mulai dilaksanakan SMA Kristen 1 Salatiga sebelum pemerintah mencanangkan program tersebut menjadi program resmi. Program pendidikan keluarga yang dilaksanakan oleh sekolah saat ini terdiri dari 2 bagian yaitu program penguatan kemitraan keluarga dan program penguatan ekosistem pendidikan. Namun dalam penelitian ini fokus pengembangan model dibatasi hanya pada pengembangan program penguatan kemitraan keluarga. Kemitraan sekolah tersebut dilakukan dengan para orang tua, alumni yang sebagian besar juga merupakan alumni sekolah serta kemitraan dengan universitas lain disekitar sekolah.

Berdasarkan hasil studi pendahulan dengan teknik wawancara dan studi dokumentasi saat survey lapangan maka dirumuskanlah model faktual kemitraan yang menjadi acuan dalam pengembangan model kemitraan sekolah dengan orang tua melalui media sosial. Model faktual ini meliputi perencanaan, pengorganisasian, pelaksanaaan dan evaluasi program kemitraan sekolah dengan orang tua. Model faktual kemitraan sekolah dengan orang tua di SMA Kristen 1 Salatiga dapat dirangkum seperti bagan model faktual kemitraan sekolah dengan orang tua di SMA Kristen 1 Salatiga sebagai berikut: 
Pengembangan Model Kemitraan Sekolah Dengan Orang Tua Melalui ... | Mutia Ayu Krismanda, dkk.
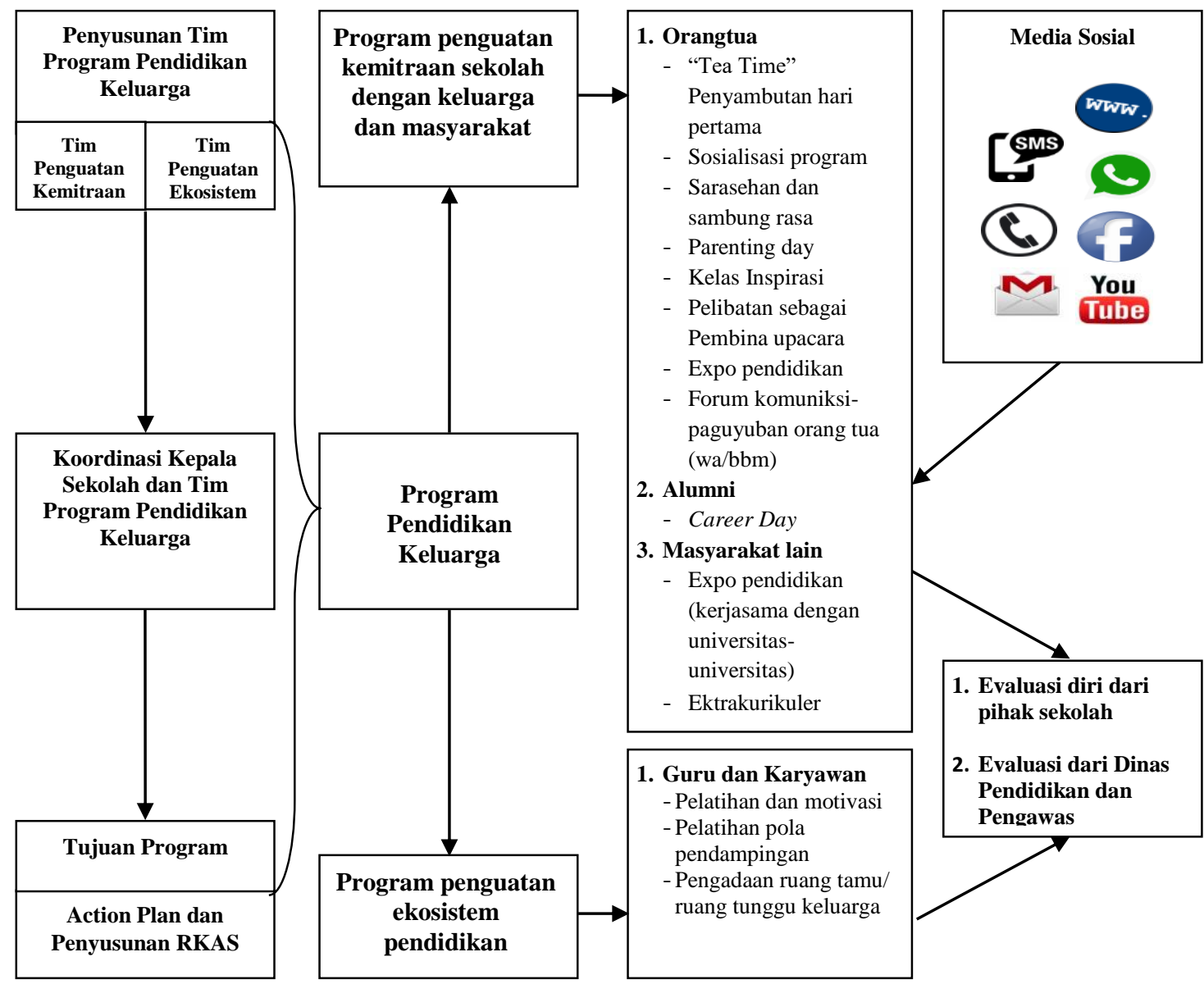

Gambar 1

Model Faktual Kemitraan Sekolah dengan Orang di SMA Kristen 1 Salatiga

Hasil evaluasi formatif juga digunakan dalam penelitian ini adalah SWOT dan MAS sebagai data menganalisis kebutuhan model. yang dipaparkan sebagai berikut: Analisis kebutuhan model yang digunakan

Tabel 1

Hasil Analisis Faktor Kekuatan dan Kelemahan Matrik IFAS (Internal Factors Analysis Summary)

\begin{tabular}{|c|c|c|c|c|}
\hline No & $\frac{\text { Faktor-faktor Internal }}{\text { Kekuatan (Strength) }}$ & Bobot & Skor & $\begin{array}{c}\text { Total Bobot } x \\
\text { Skor }\end{array}$ \\
\hline 1 & Teamwork yang solid & 0,07 & 4 & 0,28 \\
\hline 2 & Komitmen dari warga sekolah untuk mewujudkan program. & 0,07 & 4 & 0,28 \\
\hline 3 & $\begin{array}{l}\text { Kemampuan sumber daya manusia yang cukup baik dan } \\
\text { kreatif dalam mengembangkan program. }\end{array}$ & 0,1 & 4 & 0,4 \\
\hline 4 & $\begin{array}{l}\text { Sekolah juga mengadakan penguatan ekosistem untuk } \\
\text { meningkatkan kinerja sekolah. }\end{array}$ & 0,06 & 4 & 0,24 \\
\hline 5 & Sekolah memiliki moto custumor staisfication. & 0,06 & 3 & 0,18 \\
\hline 6 & Pemimpin yang humanis. & 0,07 & 3 & 0,21 \\
\hline 7 & $\begin{array}{l}\text { Pemimpin yang cukup aktif menjalin hubungan kerjasama } \\
\text { dengan pihak masyarakat. }\end{array}$ & 0,09 & 4 & 0,32 \\
\hline 8 & $\begin{array}{l}\text { Sekolah telah memiliki kesadaran untuk melaksanakan } \\
\text { beberapa kegiatan dalam program pendidikan keluarga } \\
\text { sebelum mendapatkan bantuan pemerintah. }\end{array}$ & 0,07 & 4 & 0,28 \\
\hline 9 & $\begin{array}{l}\text { Sekolah telah mengikuti pembinaan dan bimbingan teknis } \\
\text { penyelenggaraan pendidikan keluarga dari dinas pendidikan. }\end{array}$ & 0,06 & 3 & 0,18 \\
\hline
\end{tabular}




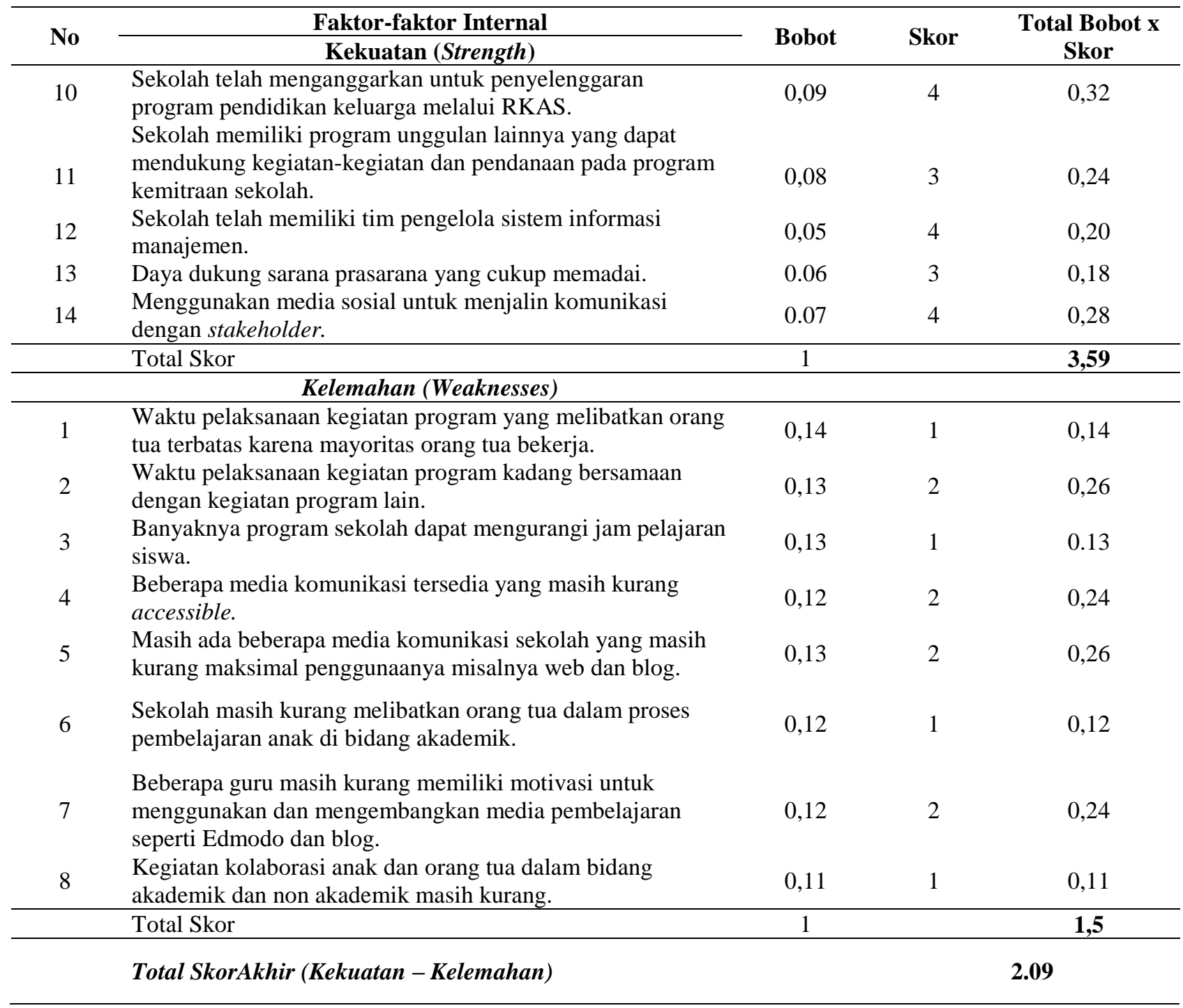

Dari data pada tabel diatas dapat disimpulkan bahwa total bobot dikalikan skor pada faktor kekuatan adalah 3,59 sedangkan total bobot dikalikan skor pada faktor kelemahan adalah 1,5 sehingga skor akhir IFAS yaitu faktor kekuatan dikurangi faktor kelemahan adalah 2,09. Hal ini menunjukkan bahwa faktor kekuatan adalah faktor yang lebih dominan dibandingkan dengan faktor kelemahan. Oleh karena itu sekolah dapat mengoptimalkan kekuatan yang dominan yang dimiliki untuk mengatasi kelemahankelemahan yang ada.

Tabel 2

Hasil Analisis Faktor Peluang dan Ancaman Matrik EFAS (External Factors Analysis Summary)

\begin{tabular}{|c|c|c|c|c|}
\hline \multirow{2}{*}{ No } & Faktor-faktor Eksternal & \multirow{2}{*}{ Bobot } & \multirow{2}{*}{ Skor } & \multirow{2}{*}{$\begin{array}{c}\text { Total Bobot } \mathrm{x} \\
\text { Skor }\end{array}$} \\
\hline & Peluang (Opportunity) & & & \\
\hline 1 & $\begin{array}{l}\text { Sekolah telah dipilih menjadi salah satu sekolah percontohan } \\
\text { program pendidikan keluarga. }\end{array}$ & 0,13 & 3 & 0,39 \\
\hline 2 & $\begin{array}{l}\text { Dukungan dana dari pemerintah berupa bantuan dana program } \\
\text { Kemitraan Sekolah dengan Keluarga dan Msayarakat serta } \\
\text { monitoring. }\end{array}$ & 0,17 & 3 & 0,51 \\
\hline
\end{tabular}


Pengembangan Model Kemitraan Sekolah Dengan Orang Tua Melalui ... | Mutia Ayu Krismanda, dkk.

\begin{tabular}{|c|c|c|c|c|}
\hline \multirow[t]{2}{*}{ No } & $\begin{array}{c}\text { Faktor-faktor Eksternal } \\
\text { Peluang (Opportunity) }\end{array}$ & \multirow[t]{2}{*}{ Bobot } & \multirow[t]{2}{*}{ Skor } & \multirow[t]{2}{*}{$\begin{array}{c}\text { Total Bobot } \mathrm{x} \\
\text { Skor }\end{array}$} \\
\hline & $\begin{array}{l}\text { Peluang (Opportunity) } \\
\text { Mendanatkan dukungan dari beberana alumni vang cukun }\end{array}$ & & & \\
\hline 3 & $\begin{array}{l}\text { Mendapatkan dukungan dari beberapa alumni yang cukup } \\
\text { berpotensi. }\end{array}$ & 0,14 & 4 & 0,56 \\
\hline 4 & Kepercayaan masyarakat masih cukup tinggi. & 0,14 & 4 & 0,56 \\
\hline 5 & Mendapat dukungan orang tua baik dari dana maupun fasilitas. & 0,15 & 4 & 0,6 \\
\hline 6 & $\begin{array}{l}\text { Beberapa komite bersedia terjun langsung membantu dan } \\
\text { mendukung kegiatan atau program sekolah. }\end{array}$ & 0,12 & 3 & 0,36 \\
\hline \multirow[t]{3}{*}{7} & Sudah terbentuknya paguyuban orang tua wali murid & 0,15 & 4 & 0,6 \\
\hline & Total Skor & 1 & & 3,58 \\
\hline & Ancaman (Threat) & & & \\
\hline 1 & Sebagian orang tua yang masih berprinsip "pasrah bongkoan" & 0,23 & 1 & 0,23 \\
\hline 2 & $\begin{array}{l}\text { Belum ada rapat rutin komite karena terhalang oleh kesibukan } \\
\text { masing-masing komite. }\end{array}$ & 0,18 & 2 & 0,36 \\
\hline 3 & $\begin{array}{l}\text { Kesibukan orang tua sehingga sulit menemukan waktu yang tepat } \\
\text { untuk mengadakan pertemuan bersama. }\end{array}$ & 0,25 & 1 & 0,25 \\
\hline 4 & $\begin{array}{l}\text { Pengetahuan media komunikasipada orang tua yang masih perlu } \\
\text { ditingkatkan }\end{array}$ & 0,18 & 2 & 0,36 \\
\hline \multirow[t]{3}{*}{5} & $\begin{array}{l}\text { Beberapa orang tua yang masih berada di kalangan ekonomi } \\
\text { menengah kebawah. }\end{array}$ & 0,16 & 3 & 0,48 \\
\hline & Total Skor & 1 & & 1,68 \\
\hline & Total SkorAkhir (Peluang - Ancaman) & & & 2,9 \\
\hline
\end{tabular}

Dari data pada tabel diatas dapat disimpulkan bahwa total bobot dikalikan skor pada faktor peluang adalah 3,58 sedangkan total bobot dikalikan skor pada faktor ancaman adalah 1,68 sehingga skor akhir EFAS yaitu faktor peluang dikurangi faktor ancaman adalah 2,9. Dari hasil analisis faktor eksternal tersebut diketahui bahwa sekolah memiliki beberapa peluang yang dapat dimanfaatkan untuk memberikan kontribusi dalam meningkatkan kemitraan sekolah dengan orangtua dan masyarakat.

Berdasarkan hasil analisis SWOT sekolah tersebut diketahui skor akhir IFAS adalah 2.09 sedangkan skor akhir EFAS adalah 2,9. Hasil analisis ini menunjukkan bahwa strategi berada di kuadran SO (strength oportunity) yang mendukung strategi agresif. Sehingga pihak sekolah semestinya dapat menggunakan kekuatan dari lingkungan internal sekolah dan meraih peluang yang ada pada lingkungan eksternal untuk kemitraan sekolah dengan orangtua. Selanjutnya setelah mengetahui hasil analisis SWOT tersebut dibuatlah strategistrategi untuk meningkatkan jalinan kemitraan sekolah dengan orang tua serta masyarakat dan meminimalisasi faktor kelemahan dan ancaman yang dapat menghambat penyelenggraan program pendidikan keluarga tersebut. Dalam hal ini peneliti mengkategorikan beberapa aspek strategi tersebut berdasarkan analisis MAS yaitu strategi yang meliputi perubahan (modify), penambahan ( $a d d)$ dan perluasan atau penyempitan (size). Hasil analisis tersebut dipaparkan sebagai berikut: 


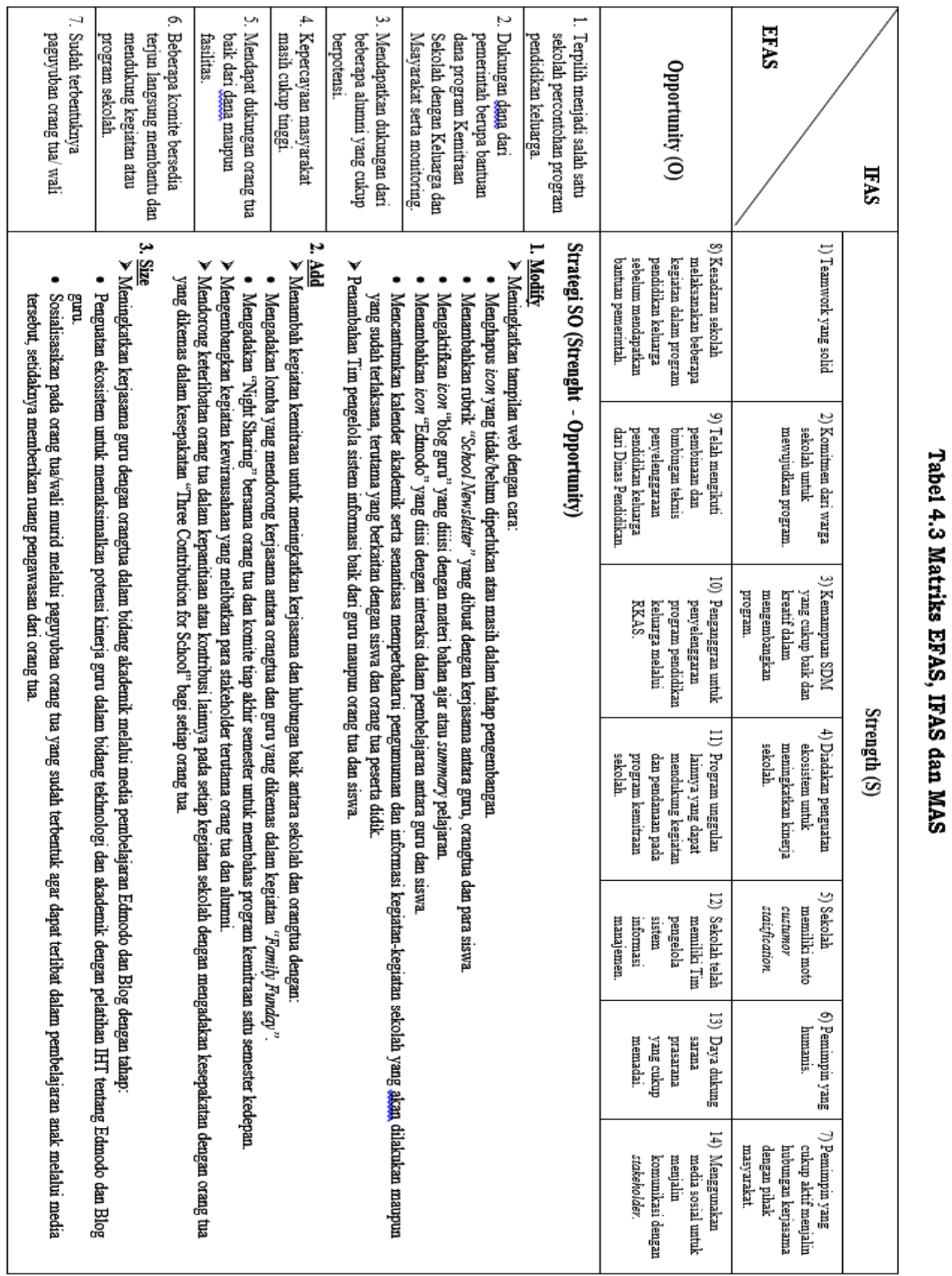

Pengembangan dalam aspek pengawasan yang mengikutsertakan orang tua pada pembelajaran akademik para siswa dapat dilakukan melalui blog guru dan Edmodo. Penggunaan blog guru dapat diisi dengan 154 summary materi pembelajaran, bahan materi tambahan, menunjukan project siswa terbaik, dll. Sedangkan penggunaan media Edmodo digunakan untuk pemberian tugas-tugas kepada siswa, diskusi diluar jam pelajaran, berbagi file, 
Pengembangan Model Kemitraan Sekolah Dengan Orang Tua Melalui ... | Mutia Ayu Krismanda, dkk.

membuat game berdasarkan standar pembelajaran dll. Aplikasi Edmodo ini juga memberi kesempatan orang tua untuk ikut bergabung didalamnya sehingga dapat turut serta mengawasi perkembangan akademik para siswa bahkan terlibat dalam proses pembelajaran anak mereka. Dalam hal ini sekolah mungkin tidak akan meminta orang tua untuk membantu mengajarkan PR mata pelajaran tertentu namun lebih kepada berbagi ide, pendapat dan bahkan pengetahuan kepada para siswa (Havard Family Research Project, 2007: 4). Contohnya dengan kolaborasi pembuatan portofolio dengan pertanyaan yag telah diarahkan oleh guru.

Selain itu, demi memperkuat komunikasi dan hubungan sekolah dengan orang tua maka sekolah dapat mengadakan acara Family Fun Day. Hal ini dapat dilakukan dengan mengadakan lomba atau kegiatan games antara orang tua dan para peserta didik yang dibuat dan dipimpin oleh trainers berpengalaman sehingga game tersebut memiliki tujuan untuk mempererat hubungan orang tua dan para peserta didik terlebih lagi dengan sekolah yang telah mengadakan acara tersebut dan berperan sebagai jembatan positif bagi mereka. Sekolah juga dapat menggunakan program "Three Contribution for School" sebagai sarana mengundang orang tua berpartisipasi sebagai relawan dalam kepanitiaan, acara-acara sekolah, pembuatan school newsletter, kegiatan dikelas, atau bahkan kegiatan sekolah yang dilakukan dirumah dll. (Corolado Springs School District 11, 2014: 6). Tentunya hal ini harus didiskusikan dan disepakati oleh orang tua atau komite sekolah sebagai perwakilan.

Program "School Newletter" merupakan sarana orang tua untuk dapat mengetahui sekolah lebih dalam lagi, setiap programnya baik yang sudah diadakan maupun yang akan dilaksanakan serta profil sekolah, profil anak berprestasi dll yang terdapat pada rubrik-rubrik didalamnya. Dalam penulisan "School Newletter" ini tidak hanya dilakukan oleh tim saja atau dari pihak sekolah namun dapat melibatkan orang tua dan para peserta didik.
Strategi lain yang dapat dilakukan yaitu melalui kegiatan Night Sharing yang dapat dilakukan sebagai solusi untuk kehadiran orang tua yang belum maksimal dalam pertemuan yang diadakan sekolah kepada orang tua. Kesibukan orang tua pada pagi hingga sore hari kerap kali menjadi hambatan dalam mengundang orang tua dalam pertemuan sekolah dengan orang tua, sehingga pertemuan tersebut menjadi kurang menjadi efektif dan efisien. Melalui kegiatan ini kedua belah pihak dapat berdiskusi jika ada beberapa hal yang perlu ditingkatkan, dirubah dan disepakati bersama dalam rangka mengasuh dan mendidik anak lebih baik lagi sehingga dapat mencetak lulusan yang unggul dalam prestasi dan karakter.

Selain memasukan unsur strategi-strategi yang telah dipaparkan diatas, pengembangan bentuk model ini mengacu pada model kemitraan sekolah dengan keluarga dan masyarakat oleh pemerintah dan dikembangkan dengan mengadaptasi dari beberapa model kemitraan yang dianggap mampu mengakomodasi kekurangan model yang sudah ada, yaitu mengadaptasi dari model PTA National Standards for Family-School Partnership dan model dari Penelitian Family Involvement in middle and High School's Education dari Havard Family Research Project. Tidak hanya itu, pengembangan model juga memadukan penggunaan media sosial dalam usaha peningkatan keefektifan komunikasi yang terjalin dalam suatu program kemitraan.

Tujuan model kemitraan sekolah dengan orang tua melalui media sosial ini adalah memberikan panduan bagi kepala sekolah, guru, tenaga kependidikan, komite serta orang tua untuk secara bersama-sama menciptakan dan mendukung pelaksanaan program kemitraan sekolah dengan orang tua dan mensukseskan pendidikan semua peserta didik. Sedangkan sasaran model kemitraan ini yaitu; Pertama, Kepala sekolah, guru, dan tenaga kependidikan sekolah swasta dalam melaksanakan kemitraan dengan keluarga dan masyarakat; Kedua, Orang tua/ wali murid 
sekolah swasta sebagai mitra kerja dalam merencanakan, melaksanakan, dan mengevaluasi program-program sekolah; Ketiga, Komite sekolah sekolah swasta sebagai mitra kerja dalam merencanakan, melaksanakan, dan mengevaluasi program-program sekolah; Keempat, Organisasi mitra yang berkaitan dengan pelaksanaan program kemitraan sekolah dengan orang tua melalui media sosial; dan kelima, Dinas Pendidikan kota dan Provinsi sebagai pembina teknis satuan pendidikan menengah dan pendidikan khusus. Spesifikasi model pengembangan kemitraan sekolah dan orang tua melalui media sosial yaitu: (1) Definisi dan deskripsi setiap bentuk kemitraan; (2) Tujuan dan hasil yang diharapkan dalam setiap bentuk kemitraan (3) Rekomendasi kegiatan yang dapat dikembangkan pada setiap bentuk kemitraan; (4) Indikator pada setiap bentuk kemitraan; (5) Peran pihak sekolah dan orang tua dalam menjalankan setiap bentuk kemitraan.

Dalam mengimplementasi model kemitraan sekolah dengan orang tua melalui media sosial ini maka pihak-pihak yang terkait harus memperhatikan setiap bentuk kemitraan yang sudah dipaparkan dalam model.
Rekomendasi kegiatan yang telah diberikan dalam model tersebut dapat dipertimbangkan sesuai dengan tahap keterlaksanaan program kemitraan sekolah serta situasi dan kondisi sekolah. Keterlaksanaan setiap indikator yang sudah dijalankan harus disertai dengan evaluasi dan supervisi yang rutin sehingga dapat mencapai keberhasilan yang maksimal. Selain itu, sekolah yang hendak menggunakan model kemitraan ini harus senantiasa berusaha memenuhi beberapa faktor yang mempengaruhi efektifitas keterlaksanaan model, seperti persyaratan pokok model, profil sekolah, peran dan karakter dan monitoring dan evaluasi. Panduan-panduan yang telah dibuat diharapkan dapat membantu pihak-pihak terkait yang akan menjalankan program kemitraan ini. Model kemitraan sekolah dengan orang tua melalui media sosial ini diharapkan penulis dapat membantu sekolah dalam mengembangkan dan melaksanakan program kemitraan sekolah dengan orang tua yang tentunya hal tersebut harus disesuaikan dengan kondisi sekolah masing-masing. Berikut ini adalah gambar model kemitraan dan orang tua melalui media sosial:

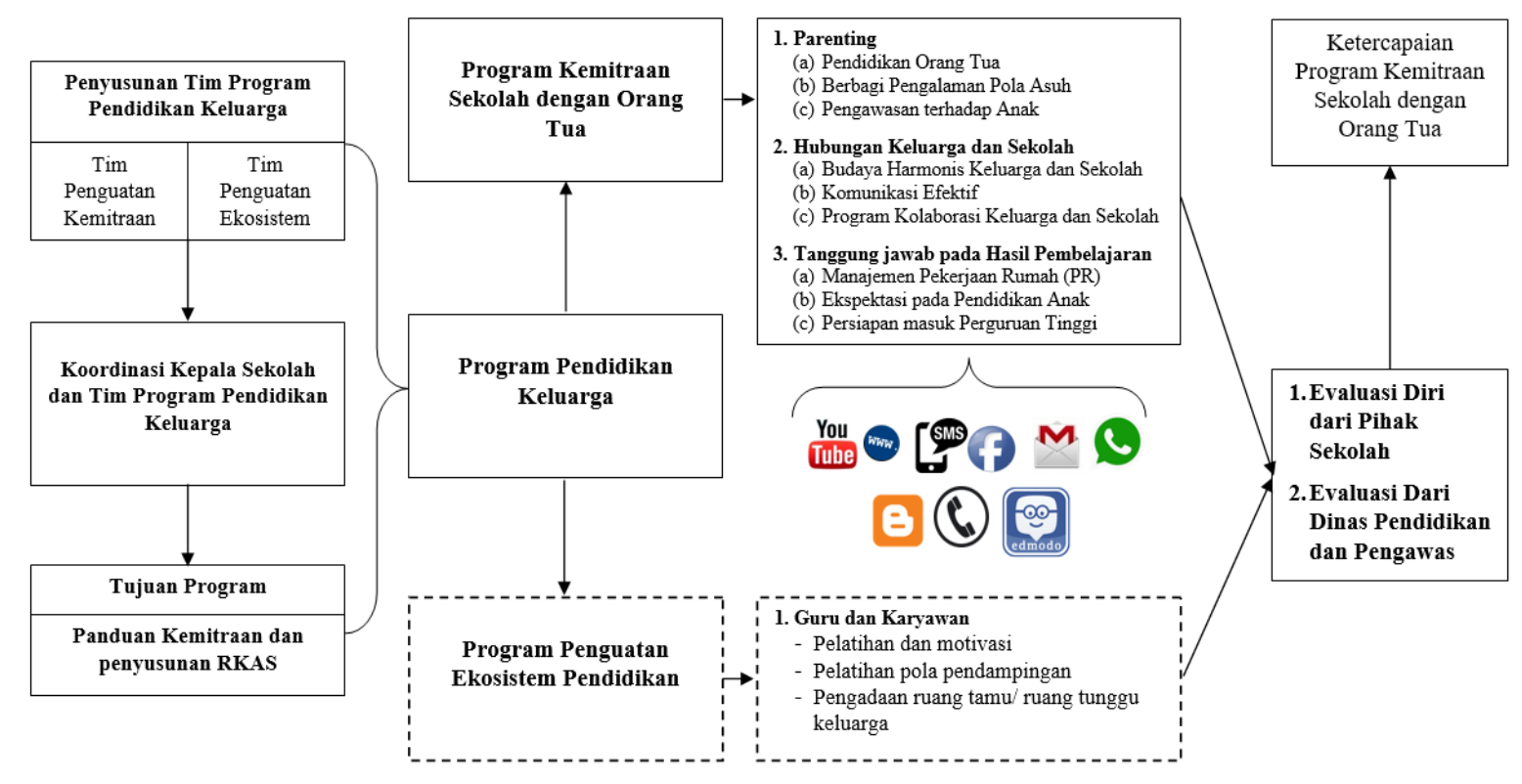

Gambar 4.2 Model Kemitraan Sekolah dan Orang tua melalui Media Sosial 


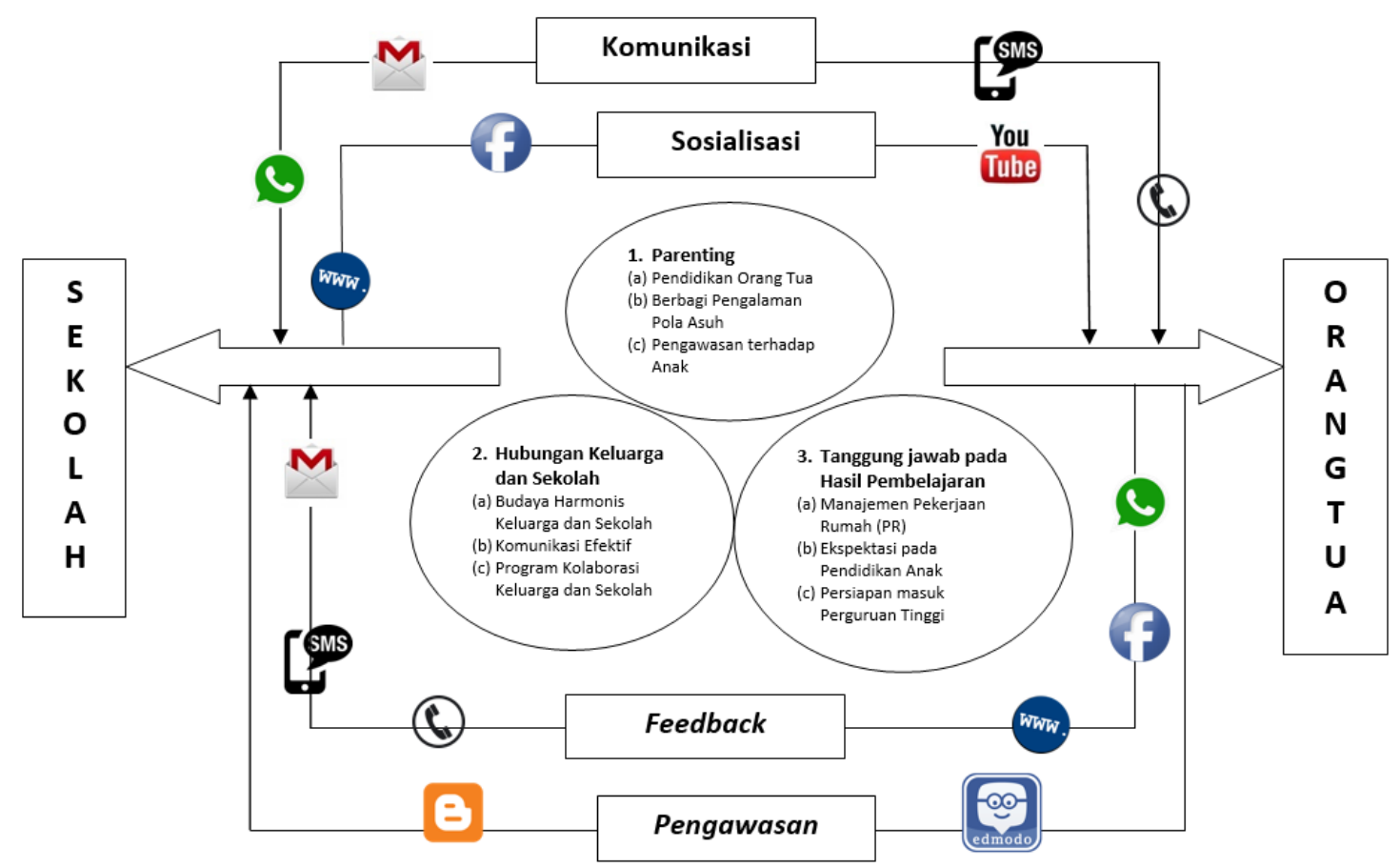

Gambar 4.3 Penggunaan media sosial dalam program kemitraan sekolah dengan orang tua

\section{Pembahasan}

Terdapat beberapa penelitian yang relevan terkait dengan penelitian ini. Penelitian oleh Mazza (2013) dan Coz (2012) memiliki kesamaan dengan penelitian ini yaitu samasama mengangkat tema kemitraan melalui media sosial. Dalam penelitiannya, Mazza hanya sebatas mendeskripsikan bagaimana penggunaan media sosial berpengaruh terhadap komunkasi antara sekolah dan para orang tua dan $\mathrm{Coz}$ mencoba mendeskripsikan, menganalisa dan mentafsirkan pengelaman beberapa kepala sekolah dan pengawas dalam menggunakan beragam alat komunikasi seperti media sosial untuk berkomunikasi dengan para pemangku kepentingan sebagai suatu sistem komunikais yang komprehensif, sedangkan dalam penelitian ini peneliti tidak hanya mendeskripsikan dan menganalisa saja namun mencoba menghasilkan suatu produk yang berupa model kemitraan sekolah dengan orang tua yang didalamnya mengandung unsur penggunaan media sosial sebagai alat penguat komunikasi dalam kemitraan tersebut. Penelitian tentang model kemitraan masih jarang ditemui di Indonesia, namun demikian peneliti menemukan satu penelitian yang hampir mirip dengan model kemitraan sekolah dengan orang tua yaitu model kolaborasi guru, orang tua dan masyarakat oleh Jamalludin (2015). Penelitian Jamalludin dan penelitian ini hampir sama yaitu mencoba membuat model yang berhubungan dengan kemitraan atau kolaborasi antara pihak sekolah dengan orang tua dan masyarakat melalui beberapa tahap, Jamalludin dengan tahap Borg and Gall sedangkan penelitian pengembangan ini menggunakan tahap Sugiyono. Namun terdapat keistimewaan produk penelitian ini yaitu dengan menambahkan penggunaan media sosial sebagai alat komunikasi yang diharapkan dapat membantu menguatkan komunikasi antar pihak terkait. Teknik analisis yang digunakan dalam penelitian ini pun juga hampir sama seperti teknik analisis yang digunakan dalam penelitian Rosita (2009) dan Prastawa (2010) yang juga menggunakan teknik analisis SWOT untuk melihat potensi kekuatan, kelemahan, hambatan dan peluang sebelum membuat strategi-strategi dalam penelitian pengembangannya, perbedaanya dalam penelitian ini untuk mendapatkan strategi-strategi dalam pengembangan model yang dibuat peneliti tidak hanya menggunakan SWOT namun juga menggunakan teknik analisis MAS untuk memaksimalkan hasil pengembangan model. 
Meskipun memiliki perbedaan, kelima penelitian yang relevan yang telah dipaparkan diatas menjadi bahan pertimbangan yang bermanfaat bagi penulisan penelitian pengembangan ini.

Keterbatasan pengembangan model kemitraan sekolah dengan orang tua dalam penelitian dan pengembangan ini meliputi hal sebagai berikut: 1) Keterbatasan pengembangan dibatasi pada studi pendahuluan di satu lingkup satu sekolah saja. Sekolah tersebut dipilih karena mayoritas baik pendidik maupun orang tua atau wali murid peserta didik telah dianggap cukup mengikuti perkembangan era digital dalam berkomunikasi. Artinya penggunaan smart phone dan media sosial cukup populer dikalangan warga sekolah.

2) Dalam menerapkan model kemitraan sekolah dengan orang tua sebagai hasil dari produk penelitian ini, satuan pendidikan dan warga sekolah harus memiliki media sosial yang prima, artinya media sosial harus dipersiapkan dengan baik penggunaanya dengan stakeholder terkait termasuk sosialisasi spesifikasi penggunaanya dan analisis kebutuhan yang harus dilakukan sebelum penggunaan, selain itu dalam penggunaanya juga harus memiliki etika dalam berkomunikasi menggunakan media sosial, etika tersebut dapat dibuat dan disepakati bersama dengan perwakilan stakeholder terkait, dan tidak kalah penting penggunaan media sosial juga harus dievaluasi untuk peningkatan komunikasi yang lebih baik. 3 Penggunaan media sosial hanya sebatas alat pendukung komunikasi dalam program kemitraan sekolah dan orang tua, tanpa budaya berkomunikasi yang baik dari sekolah ke orang tua maupun sebaliknya penggunaan alat pendukung ini tidak akan berjalan efektif. Sekolah adalah pihak pertama yang harus membangun budaya komunikasi yang baik dengan orang tua maupun masyarakat, hal tersebut dapat dilakukan melalui programprogram pertemuan sekolah dan orang tua atau masyarakat untuk menjalin komunikasi dengan baik. 4) Penelitian dan pengembangan ini hanya dibatasi sampai pada tahap uji pakar oleh para pakar yaitu ahli dibidang Manajemen dan pengamat program Pendidikan Keluarga.

\section{PENUTUP}

\section{Simpulan}

Berdasarkan hasil evaluasi formatif yang telah dilakukan dibuatkah model faktual kemitraan sekolah dengan orang tua yang dikemas dalam program pendidikan keluarga di SMA Kristen 1 Salatiga. Model faktual yang dirumuskan meliputi dari perencanaan, pengorganisasian dan pelaksanaan dan evaluasi. Dalam model faktual tersebut program dibagi menjadi dua, program penguatan kemitraan dan program penguatan ekosistem. Namun penelitan ini fokus pada pengembangan program penguatan kemitraan. Program penguatan kemitraan keluarga merupakan program yang bertujuan untuk menguatkan jalinan kemitraan antara orang tua maupun masyarakat. Beberapa media sosial juga telah digunakan sekolah sebagai media pendukung dalam memperkuat komunikasi antara sekolah dengan stakeholder lainnya termasuk orang tua, namun pengembangan manajemen penggunaannya dirasa belum maksimal.

Demi meningkatkan mutu sekolah melalui peningkatan peran serta masyarakat pada pengelolaan sekolah yang merupakan salah satu pilar MBS dibuatlah pengembangan model kemitraan sekolah dengan orang tua melalui media sosial. Model yang dihasilkan terdiri dari pendahuluan, rasional model, spesifikasi model, bentuk-bentuk kemitraan dan indikator tiap bentuk, gambar model, efektifitas model, dan dilengkapi dengan panduan-panduan pelaksanaan. Produk yang berupa model kemitraan sekolah dengan orang tua melalui media sosial yang telah disusun diharapkan dapat membantu dan memberi inspirasi bagi sekolah yang hendak atau sedang menyelenggarakan program kemitraan sekolah dengan orang tua agar implementasi yang dilaksanakan sesuai dengan rancanganrancangan yang telah dirumuskan. 
Pengembangan Model Kemitraan Sekolah Dengan Orang Tua Melalui ... | Mutia Ayu Krismanda, dkk.

\section{Saran}

Bagi sekolah yang menyelenggarakan program kemitraan sekolah dengan orang tua agar peng-implementasian model program kemitraan sekolah dengan orang tua melalui media sosial berjalan dengan efektif, maka disarankan:

1) Penyelenggaraan dapat mencakup semua bentuk kemitraan yang sudah dikembangkan oleh peneliti.

2) Saran yang telah dibuat dalam matrik EFAS IFAS dalam bentuk MAS agar dapat dilaksanakan.

3) Kegiatan perlu diakhiri dengan evaluasi sehingga terlihat ketercapaian pada setiap bentuk kemitraan sesuai dengan tujuan dan indikator yang ada.

4) Pihak sekolah dan orang tua/ wali murid dan masyarakat yang menjalankan program kemitraan sekolah dan keluarga hendaknya selalu menjaga berkomitmen terhadap pelaksanaan kegiatan, pengadaan sarana dan prasarana serta pendanaan.

Bagi penelitian selanjutnya dapat dilakukan penelitian pengembangan dengan topik yang sama namun dengan langkah pengembangan Sugiyono yang lebih dari tahap lima atau melanjutkan penelitian ini ke tahap pengembangan selanjutnya, serta menyertakan orang tua dan yayasan sekolah sebagai narasumber wawancara untuk mendapatkan data yang lebih luas.

\section{DAFTAR PUSTAKA}

Armansyah. 2009. Peranan dan Pemberdayaan Komite Sekolah Dalam Pemberdayaan Pendidikan SMA Negeri Kota Binjai. Medan: Universitas Sumatera Utara.

Cox, Daniel Dean. 2012. "School communications 2.0: A social media strategy for $\mathrm{K}-12$ principals and superintendents". Graduate Theses and Dissertations.Paper 12301.Iowa State University.

Daryanto, Farid. 2013. Konsep Dasar Manajemen Pendidikan di Sekolah. Yogyakarta: Gava Media.
Gelgel, I Nengah. 2005. Evaluasi Kinerja Komite Sekolah Jenjang Sekolah Menengah Pertama (SMP) Di Kabupaten Buleleng Tahun 2005. IKIP Negeri Singaraja.

Greenfield, D.B. (2003).Parent Involvement Project. http://www.psy.miami.edu/ faculty/dgreenfield/research/parent_invo lvement.html.

Havard Family Research Project, 2002. Family and School Together: Building Organizational Capacity for Family School Partnership. Havard: Havard College.

Havard Family Research Project, 2007. Family Involvement Makes A Difference: Evidence That Family Involvement Promotes School Success For Every Child of Every Age. Havard: Havard College.

Jamaluddin. 2015. Model Kolaborasi Guru, Orangtua Dan Masyarakat di Satuan Pendidikan Dasar (Studi Pengembangan Di SD Negeri Inpres 1 Kabupaten Barru Kementrian Pendidikan dan Kebudayaan. 2015. Petunjuk Juknis Penguatan Kemitraan Keluarga, Satuan Pendidikan, SMA/ SMK.

Larasati, S.Y. 2009. Peran Komite Sekolah Dalam Meningkatkan Mutu Pendidikan Di SMA Ronggolawe Kota Semarang. Semarang: Universitas Negeri Semarang. Mazza, Joseph. 2013. The Use of Social Media Tools By School Principals To Communicate Between Home And School. A Dissertation. United States: ProQuest LLC

Mulyasa. 2012. Manajemen dan Kepemimpinan Kepala Sekolah. Jakarta: Bumi Aksara

Mulyono, W.D. 2014. Peran Komite Sekolah Dalam Penyelenggaraan Pendidikan SMK Di Kabupaten Lamongan, Jawa Timur. Jurnal Pendidikan Vokasi, 4/3, November 2014. Yogyakarta: UNY

Prastawa.H, dkk. 2010. Pengembangan Hutan Pinus Masyarakat Berbasis Kemitraan 
Kelola: Jurnal Manajemen Pendidikan, Vol. 4, No. 2, Juli-Desember 2017

Sebagai Model Pemberdayaan

Masyarakat Sekitar Hutan. Jurnal Teknik Industri, 11/2, Agustus 2010: 178-183.

Rodliyah. 2013. Partisipasi Masyarakat Dalam Pengambilan Keputusan dan Perencanaan di Sekolah. Yogyakarta: Pustaka Pelajar.

Rosita, Tita. 2009. Pengembangan Model Pola Pengasuhan Berbasis Keluarga di Panti Asuhan Dalam Meningkatkan Kreativitas
Seni Anak (Studi Deskriptif Tentang Pengasuhan Di Kinderdorf SOS Desa Taruna Lembang. Bandung: Universitas Pendidikan Indonesia.

Slameto. 2015. Manajemen Berbasis Sekolah (MBS). Salatiga: satya Wacana University Press.

Syaifudin, M. dkk. 2006. Manajemen Berbasis Sekolah. Jakarta: Dirjen Dikti. 